\title{
An infant with epilepsy: don't forget the importance of skin examination
}

\author{
Priyanka Madaan, ${ }^{1}$ Nanaji Rao Pala, ${ }^{2}$ Lokesh Saini $^{1}$
}

'Pediatrics, Post Graduate Institute of Medical Education and Research, Chandigarh, India ${ }^{2}$ Pediatrics, Guntur Medical College, Guntur, Andhra Pradesh, India

\section{Correspondence to} Dr Lokesh Saini,

drlokeshsaini@gmail.com

Accepted 7 August 2019

\section{DESCRIPTION}

A 4-month-old, developmentally normal girl presented with four episodes of right focal seizures. She had an uneventful perinatal period and no significant family history. Clinical examination revealed normocephaly, and hypopigmented whorls along Blaschko's lines over left anterior trunk, back (left > right), both upper limbs and left leg (figure 1). Brain MRI revealed left hemimegalencephaly (figure 2). There was no preceding history of vesicular or verrucous lesions. She was diagnosed as hypomelanosis of Ito (HI) and initiated on oral phenytoin and multisensory stimulation.

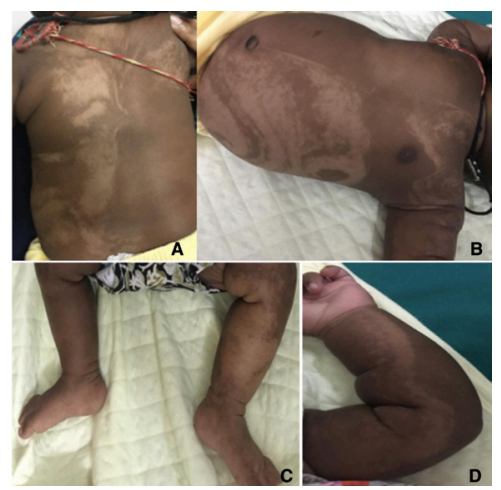

Figure 1 Skin findings in the index child. Note the hypopigmented whorls following Blaschko's lines (A) over the back (right >left), (B) abdomen, chest (left-sided), (C) left leg and (D) left arm.

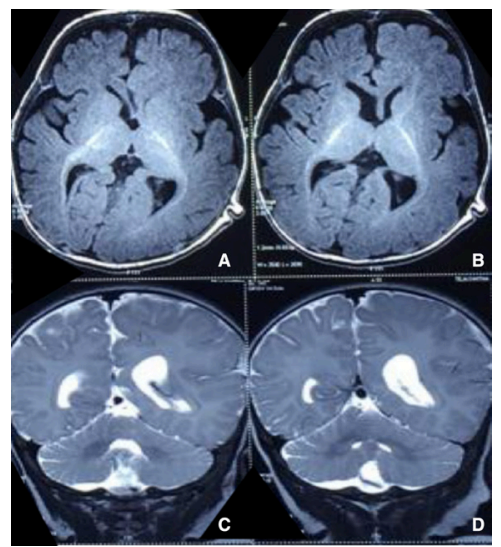

Figure 2 Brain MRI of the index child. (A,B) Axial T1-weighted and $(C, D)$ coronal T2-weighted images showing enlarged left hemisphere and prominence of occipital horn of the left lateral ventricle suggestive of left hemimegalencephaly.
HI (also known as incontinentia pigmenti achromians) is neurocutaneous symptom complex characterised by the presence of whorled hypochromic skin lesions often associated with systemic manifestations. ${ }^{12}$ Incontinentia pigmenti (with preceding vesicular or verrucous phases) is an important differential diagnosis. HI is often associated with systemic abnormalities such as ophthalmologic and skeletal abnormalities, brain and cardiac malformations. ${ }^{13}$ Neurological manifestations include epilepsy, developmental delay, autistic features, brain malformations such as agenesis or dysplasia of the corpus callosum, hemimegalencephaly and arteriovenous malformations. ${ }^{13}$ Epilepsy has been reported in up to $50 \%$ of patients.

Even in the absence of epilepsy, a neuroimaging may be warranted in a florid dermatological presentation. Also, the importance of skin examination cannot be understated even if the dermatological findings are subtle such as ash leaf macules and so on.

\section{Learning points}

- Hypomelanosis of Ito ( $\mathrm{HI})$ is characterised by whorled hypochromic skin lesions along Blaschko's lines.

- Incontinentia pigmenti is an important differential diagnosis.

- HI may be associated with systemic abnormalities such as brain malformations and so on, and these should be actively looked for.

Contributors PM: prepared the initial draft of manuscript and reviewed the literature. NRP, LS: critical review of the manuscript and reviewed the literature, edited the final version of manuscript. All the authors approved the final version of manuscript.

Funding The authors have not declared a specific grant for this research from any funding agency in the public, commercial or not-for-profit sectors.

Competing interests None declared.

Patient consent for publication Parental/guardian consent obtained.

Provenance and peer review Not commissioned; externally peer reviewed.

\section{REFERENCES}

1 Ruggieri M, Pavone L. Topical review: hypomelanosis of ito: clinical syndrome or just phenotype? J Child Neurol 2000;15:635-44.

2 Sybert VP. Hypomelanosis of Ito: a description, not a diagnosis. J Invest Dermatol 1994;103:S141-3.

3 Schwartz MF, Esterly NB, Fretzin DF, et al. Hypomelanosis of Ito (incontinentia pigmenti achromians): a neurocutaneous syndrome. J Pediatr 1977;90:236-40. 
Copyright 2019 BMJ Publishing Group. All rights reserved. For permission to reuse any of this content visit https://www.bmj.com/company/products-services/rights-and-licensing/permissions/

BMJ Case Report Fellows may re-use this article for personal use and teaching without any further permission.

Become a Fellow of BMJ Case Reports today and you can:

- Submit as many cases as you like

- Enjoy fast sympathetic peer review and rapid publication of accepted articles

Access all the published articles

Re-use any of the published material for personal use and teaching without further permission

Customer Service

If you have any further queries about your subscription, please contact our customer services team on +44 (0) 2071111105 or via email at support@bmj.com.

Visit casereports.bmj.com for more articles like this and to become a Fellow 